\title{
Anticipated Election Result and Protest Voting: Why and When Canadian Voters Signal Discontent
}

\author{
Christian H. Schimpf ${ }^{1,2 *}$ (iD) \\ ${ }^{1}$ GESIS Leibniz Institute for the Social Sciences, Kaiserring 10-16, 68159 Mannheim, Germany and \\ ${ }^{2}$ Graduate School of Economic and Social Sciences, (University of Mannheim), B6, 30-32, 68159 \\ Mannheim, Germany \\ *Corresponding author. E-mail: cschimpf@mail.uni-mannheim.de
}

\begin{abstract}
This article investigates how Canadian voters react to a perceived lack of quality provided by their most preferred parties and how the anticipated election outcome conditions the reactions. The central argument is that a lack of quality motivates voters to signal their discontent by voting insincerely-that is, they cast a protest vote. The effect is expected to be moderated by the anticipated constituency result. The arguments are tested with two-wave panel survey data from the 2015 Canadian federal election, collected by the Making Electoral Democracy Work (MEDW) project. The results support the central argument but remain inconclusive about the expected moderating effects.
\end{abstract}

\section{Résumé}

Cet article examine comment les électeurs canadiens réagissent à la perception d'un manque de qualité de la part de leurs partis favoris et comment le résultat électoral prévu conditionne leurs réactions. L'argument central est qu'un manque de qualité motive les électeurs à manifester leur mécontentement en votant hypocritement, c'est-à-dire par un vote protestataire. On s'attend à ce que l'effet soit modéré par le résultat escompté dans la circonscription. Les arguments sont soumis à un test à l'aide des données d'une enquête par panel en deux vagues du projet Making Electoral Democracy Work (MEDW), recueillies autour de l'élection fédérale canadienne de 2015. Les résultats appuient l'argument central, mais demeurent peu concluants quant aux effets modérateurs attendus.

Keywords: Protest voting; 2015 Canadian federal election; third parties; signaling; strategic voting

\section{Introduction}

While many Canadians vote with their hearts and cast their ballot for the party they prefer most, a reasonable share of people in every election deviates by casting an insincere vote. A common explanation in the literature for this behaviour is that

(C) Canadian Political Science Association (l'Association canadienne de science politique) and/et la Société québécoise de science politique 2019. This is an Open Access article, distributed under the terms of the Creative Commons Attribution licence (http://creativecommons.org/licenses/by/4.0/), which permits unrestricted re-use, distribution, and reproduction in any medium, provided the original work is properly cited. 
insincere voting is a form of strategic voting in which voters abandon their most preferred party if it stands little chance of winning the constituency seat (see, for example, Blais, 2002; Merolla and Stephenson, 2007). Few studies, however, focus on the expressive "face" (Franklin et al., 1994) of an insincere vote: the protest vote. The general premise of such a vote is that voters utilize their ballot to send their party a signal of perceived shortcomings by temporarily withdrawing their support and voting for another party (Kselman and Niou, 2011). The existing literature on protest voting in Canada focuses on the connection between different forms of dissatisfaction and a third-party vote (Bélanger, 2004; Bowler and Lanoue, 1992), particularly in western Canada (Bickerton, 2016). In some studies, only a vote for third parties is even considered a protest vote (McGregor, 2012). The party approach to protest voting, however, can result in theoretical circularity (Van der Brug et al., 2000) or extensive overlap with other voting models-for example, valence voting (Alvarez et al., 2018). More importantly, because the spotlight in these studies is on whom disenchanted voters choose, we know less about the first step of protest voting-namely, why and when voters decide to act on their discontent and cast an insincere vote (Birch and Dennison, 2019; Weber, 2011). The goal of this article is to revisit protest voting in Canada and adopt a voter's perspective as a way to look at this first step. Understanding how and when protest voting occurs addresses timely questions, as both Canadian political pundits and experts regularly note that fake news (Bryden, 2019) and populism (Graves and Valpy, 2018) are playing a greater role in contemporary Canadian politics, leading to an unstable political climate that may lead angry citizens to cast protest votes.

The article's intended contribution is threefold. The first contribution involves empirical insights into the underlying foundation of a protest vote and the interaction between its two dimensions: the protest motive and the insincere vote. The central argument is that voters who perceive their most preferred party as lacking quality in a given area are more likely to vote insincerely to signal their dissatisfaction (Hirschman, 1970; Weber, 2011). In addition to explaining protest voting, these insights help explain why some Canadians vote insincerely. The second contribution is an empirical test of potential moderating effects of strategic considerations on protest voting. A string of recent studies suggest two ways in which these effects may play out-namely, that voters are more likely to cast a protest vote if they are certain their party has secured the win or if they expect an election to be noncompetitive (Kselman and Niou, 2011: 408; Myatt, 2017: 1541). The third contribution is an extensive discussion of the challenges involved in conceptualizing "protest voting" using an operationalization that differs from that used in the majority of the existing literature. The choices made in this article may therefore also inform future debates and research on protest voting.

Using data from the Making Electoral Democracy Work (MEDW) project (Cross et al., 2017), I find evidence for the general mechanism of protest voting in the 2015 federal elections. Voters who perceive their most preferred party to lack quality were more likely to defect and vote insincerely - that is, to cast a protest vote. The findings, however, do not suggest that the decision to cast a protest vote is conditioned by strategic considerations. Neither the perceived chances of winning the constituency seat nor the expected electoral competition consistently conditions the marginal effect of quality on insincere voting behaviour in the theoretically expected ways. 
In the following section, I clarify the concept of protest voting. The subsequent sections develop a series of hypotheses, describe the research strategy for and the results from my empirical analyses, and offer a concluding discussion and summary.

\section{Defining a Protest Vote}

In this article, I define a protest vote as an insincere vote (behaviour) intended to signal discontent (motive) to a voter's most preferred party (Heath et al., 1985: 113; Kang, 2004; Kselman and Niou, 2011; Meirowitz and Tucker, 2007; Weber, 2011). There are thus two dimensions to protest voting: behaviour and motive. Each dimension allows the concept to be distinguished from similar concepts. The insincere vote is crucial because it distinguishes protest voting from other models of voting, such as proximity voting (Downs, 1957) or valence voting (retrospective voting) (Healy and Malhotra, 2013). According to the latter, for instance, voters evaluate parties and politicians based on their performance. Depending on the outcome, voters either vote for or against the party they evaluate (Fiorina, 1981; Key, 1966). While protest voters and valence voters are similar, protest voters who cast a ballot abandon their most preferred choice temporarily-as Weber (2011: 908) puts it, they register their "voice-by-choice." Thus, classical valence voters are sincere in that they switch to punish poor performance (see, for example, Stiers, 2018). Protest voters, on the other hand, vote against their most preferred party or group of parties in order to achieve changes beyond the current election (Kang, 2004: 81). As Alvarez et al. (2018: 141) point out in their comprehensive review of the protest voting literature, scholars too often equate protest voting with conventional retrospective voting. The emphasis on insincerity helps to distinguish the different models.

As a protest vote is insincere, some scholars describe it as a form of strategic or tactical voting (Alvarez et al., 2018: 142; Franklin et al., 1994; Meirowitz and Tucker, 2007: 88). Protest voting and strategic voting (as more commonly defined), however, should and can be distinguished both conceptually and empirically based on their underlying motives. Strategic voters seek to influence the election outcome in pivotal situations (Blais et al., 2005; Fisher, 2004; Herrmann et al., 2016). In the words of Blais et al., "a strategic vote is a vote for a party (candidate) that is not the preferred one, motivated by the intention to affect the outcome of the election" (2001: 344, italics in original). In the Canadian context, strategic voting can occur, for instance, when voters perceive their preferred party's constituency candidate as having little or no chance of winning the seat. Rather than wasting their vote (Cox, 1997: 70), voters abandon their preferred party and vote insincerely to maximize their influence on the election outcome (Blais et al., 2018: 89). Thus while an insincere vote is observed in both strategic and protest voting, there are two key differences. First, strategic voters care about the outcome of the pending election when making their decisions. In contrast, protest voters, at the time of their decision making, seek to achieve some long-term goal beyond the current election (McMurray, 2017; Meirowitz and Shotts, 2009; Meirowitz and Tucker, 2007; Myatt, 2017). Second, and even more important, the underlying motives to vote insincerely differ between the two types: whereas strategic voters are motivated by wanting to influence an election outcome, protest voters are motivated by wanting to signal discontent stemming from perceived failures of their most preferred party. 
The final point in this section concerns the frequent linkage made between protest voting and specific types of parties. Protest voting is often limited to, or primarily associated with, a vote for populist parties (Ivarsflaten, 2008; Schumacher and Rooduijn, 2013) or third and minor parties (Denemark and Bowler, 2002; McGregor, 2012). While these types of parties may well be the primary beneficiaries of protest voting in some contexts, equating the vote for a protest party (or any specific type of party) with protest voting can lead to theoretical circularity (Van der Brug et al., 2000: 82): voters are "protest voters" because they vote for a "protest party." To circumvent this problem, the definition used here rests on Birch and Dennison's recommendation to consider protest voting "in terms of the vote, not the party" (2019: 111). Consequently, citizens may engage in protest voting irrespective of the party they support, and protest voting becomes a two-step process. First, voters decide to cast a protest vote; second, they chose whom to cast their vote for. By not equating a protest vote with a vote for a third party, we are able to ask, for instance, under what conditions third parties can attract protest votes (Bowler and Lanoue, 1992; Burden, 2005).

In summary, protest voting is defined by two components: the signalling of discontent (the motive) and an insincere vote (the behaviour). Rather than focusing on the question of for whom protest voters vote, as has been done in previous studies (see, for example, Bélanger, 2004; Bowler and Lanoue 1992), this article addresses the underlying foundations of protest voting in Canada to illuminate why and when voters opt to cast a protest vote. In the subsequent section, I map out the "micro-logic" (Weber, 2011) of the protest vote in order to unravel the relationship between the two dimensions, discontent and insincere voting. I theorize why a perceived lack of quality should lead to insincere voting in the first place and how the relationship between the two is affected by strategic considerations related to electoral competition at the district level.

\section{Protest Voting-Basic Mechanism and Expected Election Result}

The underlying micro-logic (Weber, 2011) of protest voting is based on Hirschman's (1970) trailblazing work, Exit, Voice, and Loyalty. One of the book's central ideas is that a perceived decline in the quality of a good leads to dissatisfied customers (here, eligible voters) who can choose to make their voices heard. The term quality describes the criterion that customers use to evaluate their suppliers. Drawing on this idea, Weber (2011) and Kang (2004) show that the term can also be used to describe the diverse set of criteria that citizens use to evaluate political parties. For instance, quality may refer to party leadership (see, for example, Polk and Kölln, 2018), policy congruence (Myatt, 2017) or the ability of parties to handle voters' most important issues (Weber, 2011). But while there are multiple manifestations of quality in politics, the mechanism is identical across all of them (Weber, 2011: 910): supporters of parties who perceive that their most preferred party fails to live up to the supporters' standards become more likely to cast an insincere vote to signal their dissatisfaction - that is, they cast a protest vote. ${ }^{1}$ Put differently, citizens utilize their vote to communicate their evaluations to political parties (Piketty, 2000). ${ }^{2}$ In their study of party members in Sweden and Great Britain, Polk and Kölln (2018), for instance, find that ideological 
distance between party members and their parties predicts defection in national elections. Weber (2011) unravels similar patterns in his study on the 1999 and 2004 European parliamentary elections. He shows, for instance, that voters are willing to temporarily withdraw their support for their most preferred party if they perceive a large enough ideological gap between themselves and their party. The key assumptions behind this mechanism are that voters attempt to maximize their utility, believe their vote matters, believe they can freely choose between different options and are aware of existing options.

H1: The lower the perceived quality offered by a voter's most preferred party, the more likely the voter is to cast an insincere vote.

Even though there is a view that protest voters are not voting to elect a winner (Carter and Guerette, 1992), some argue that protest considerations are moderated by strategic considerations related to the election outcome. Cox, for example, proposes that voters have an opportunity to send a signal to major parties but only if "the constituency result is a foregone conclusion" (Cox, 1997: 83). This proposition has been adopted in a number of theoretical studies (Kselman and Niou, 2011; Myatt, 2017; Razin, 2003), and Alvarez et al. write: "Instead of abandoning a party with no chance of winning, however, protest voters vote for another party to signal dissatisfaction with their most preferred party, which they are confident is going to win" (2018: 142). The rationale is that voters still want the party that represents them the best to win, in order to maximize their utility. Once voters perceive that this goal is being achieved, they may consider defecting to correct for a lack of quality, as it further increases their utility if a political party eventually reacts to their protest. There are reasons, however, to question this rationale. Strategic voting hinges on pivotal situations where a single vote makes a difference (Herrmann et al., 2016: 586). But even though voters tend to overestimate their influence on the election outcome at times (Duffy and Tavits, 2008), pivotal situations are not the norm (see, for example, Fraga and Hersh, 2018: 303). One possible consequence of the lack of true pivotal situations is "that pivot events are not of first-order importance when rational voters take into account the future effects of their votes" (Meirowitz and Shotts, 2009: 747). Hence, even in situations where voters encounter the possibility of casting a strategic vote, they may be less willing to do so and instead give more importance to other motives. To test these competing views empirically, I derive two hypotheses about how strategic considerations can influence the proposed relationship between protest considerations and insincere voting. Because winning in the context of Canadian elections is generally tied to the constituency results, the focus of this article is on strategic considerations related to the constituency level. The first of these hypotheses follows directly from the discussion above of how protest considerations cause insincere voting only if a voter is certain their most preferred party has secured the win:

$\mathrm{H} 2$ : The more certain voters are that their most preferred party will win the constituency seat, the greater the effect of party quality on insincere voting. 
The second hypothesis extends the argument to voters who may not perceive their party as winning but still consider the election result settled (Kselman and Niou, 2011: 407). For instance, a voter of the eventual runner-up party in a constituency may decide to cast a protest vote not because their party is assured of winning but because they perceive that the race is already decided in favour of another party. Whether their party is in the lead or behind, perceived noncompetitive races should increase voters' willingness to signal any lack of quality to their most preferred party.

H3: The less competitive that voters expect the constituency race to be, the greater the effect of party quality on insincere voting.

$\mathrm{H} 2$ and $\mathrm{H} 3$ imply that the relationship between the two dimensions of protest voting is moderated by strategic considerations. If these hypotheses hold, then protest voting is not a tool for voters to hold parties accountable. If winning trumps quality concerns at all times, parties cannot learn about voters' concerns from election results, specifically in consistently competitive races, both objectively and subjectively.

In the following section, I describe my empirical strategy aimed at achieving two goals: first, to understand the underlying foundations of a protest vote; and second, to understand how these foundations are altered by strategic considerations.

\section{Research Strategy}

To test my hypotheses, I use data from the Making Electoral Democracy Work project (Blais, 2010) that were collected in a two-wave online survey focused on the 2015 Canadian federal election (Cross et al., 2017), which was held on October 19, 2015. The pre-election wave was fielded between October 9 and October 18, 2015, and the post-election wave between October 20 and November 6, 2015. The surveys were fielded in three Canadian provinces, British Columbia $(N=1,869)$, Ontario $(N=1,891)$ and Quebec $(N=1,849)$, which combined are home to approximately 75 per cent of all Canadians. Respondents were recruited panel members, selected according to quotas (age, gender, education and region), and the survey is meant to be representative of eligible voters with respect to the quota criteria. All survey questions related to parties were asked about the Conservative party, the New Democratic party, the Liberal party, the Bloc Québécois (in Quebec only), and the Green party. Hence, all subsequent discussions and analyses focus on these five parties.

\section{Dependent variable}

The dependent variable is a dummy variable with "sincere voting" as the baseline category $(0=$ sincere vote; $1=$ insincere vote $)$. A sincere vote is measured as a vote for the party a voter prefers the most. To determine sincere voting preferences, I use an 11-point scale on which respondents were asked to rate the main parties (like/ dislike) competing in their province. I chose the like/dislike scores over party identification, which is conceived of here as a social identity (Campbell et al., 1960). As Gidengil et al. (2012: chap. 4) show, party identification has not only played a 
meaningful role in contemporary Canadian politics but is also stable enough to justify a social identity perspective. Moreover, the measurement of preferences using like/dislike scores follows prominent examples in the protest voting and strategic voting literatures, as well as elsewhere (Blais et al., 2017; Blais et al., 2005; Weber, 2011). To code voters as sincere/insincere, the following rules were applied: If the respondent rated two or more parties as their most liked parties, they were asked a follow-up question to break the tie and identify which of the parties they liked the most. Respondents were coded as sincere if they reported in the postelection survey that they voted for the party they had said they liked most in the pre-election survey; they were coded as insincere if their vote choice deviated from their sincere preference. ${ }^{3}$

On the basis of the coding, I restrict the primary analyses to those respondents whose previous vote choice (2011 federal election) is identical to their most preferred party. This approach follows Weber's (2011: 913) proposition on how to distinguish protest voters from potential switchers, which is not the focus of the article. From a theoretical view, this restriction accounts for the suggested dynamic long-term perspective of those who cast a protest vote, as well as the idea that parties can rely on previous election results to adjust their positions in current elections (see, for example, Somer-Topcu, 2009). ${ }^{4}$

\section{Independent variables}

I use two different measures of party quality: 1) the perceived ideological congruence between a voter and the voter's preferred party, and 2) the perceived competence of the voter's preferred party to handle voters' most pressing issues. These measures capture two important aspects of a party for voters-namely, how well a party represents them and the party's competence to deliver (Kang, 2004; Weber, 2011: 908). ${ }^{5}$ In line with the proposed theoretical mechanism, these measures capture two aspects that voters can use to evaluate parties. Ideological congruence is a measure for how well a party represents their voters' positions overall. Hence, an increase of incongruence should increase the probability of an insincere vote. Ideological congruence is measured as the absolute distance between a voter's self-placement on an 11-point left-right scale and the placement of their most preferred party on an identical scale. Greater absolute distances indicate less congruence between a voter and the voter's party. ${ }^{6}$ The second measure-competence to handle voters' most important issues-combines information from two survey questions. First, respondents were asked if any party could handle the issue most important to them in the current federal election. If they answered yes, they were asked which party they considered best suited to handle the issue. The combined variable has two categories, indicating if the most preferred party is best suited to handle the issue (0) or not (1). Respondents are coded in the same way regardless of what type of issue was most important to them. The nature of the issue should only play a role in explaining which parties insincere voters choose (a question beyond this article's scope) but not if they vote insincerely in the first place.

Respondents were also asked to rate each party's chance of winning the local constituency on a scale from 0 to 10 . To account for the relativity of win chances, the rating that respondents gave their most preferred party was divided by the sum 
of scores they gave to all parties whose chances they were asked to rate. The measure thus ranges from 0 (no chance to win at all) to 1 (will certainly win). Finally, respondents were asked how competitive they expected the election outcome in their constituency to be on a four-point scale $(0=$ "not close at all" to $4=$ "very close"). All four variables were measured in the pre-election survey.

\section{Covariates}

All models include a dummy variable to capture whether respondents identify with the party they prefer most (dummy: yes/no). ${ }^{7}$ As in previous work on protest voting (Weber, 2011), this variable is intended to measure the loyalty of voters to their most preferred party. Theoretically, loyalty plays a dual role in protest voting. On the one hand, loyal voters may benefit the most from casting a protest vote if parties react to their signals accordingly; hence, they might be more likely to cast a protest vote (see, for example, Gehlbach, 2006). Evidence for this is found by Weber (2011) but also in the related literature on partisan defection, where studies have shown that otherwise loyal followers are willing to defect in the wake of perceived shortcomings (Beck, 2002; Cain and Ferejohn, 1981). On the other hand, loyal followers may be those who would rather "suffer in silence" than communicate their discontent (Barry, 1974: 97). The dummy is to adjust for either of these tendencies. In addition to party identification, I adjust for how important the election outcome in their district and nationwide is to respondents because of its potential relationship to protest voting and the outcome (Franklin et al., 1994).

Regarding political leaders and candidates, I include two variables that indicate if respondents prefer a district candidate and/or a national party leader other than the ones from their most preferred party better (dummies: yes/no). This is to account for respondents voting for a local candidate or national candidate rather than a party, for which there is empirical evidence in Canada (Bittner, 2018; Blais and Daoust, 2017). ${ }^{8}$ Finally, I adjust for a set of demographic variables (age, gender, education) and the province of respondents in order to control for unobserved heterogeneity, specifically that resulting from the additional political dimension in Quebec. All covariates were measured in the pre-election survey. For descriptive statistics, question wording and further coding details, see section A of the Online Supplementary Material.

\section{Methodology}

To test my hypotheses, I use logistic regression models with insincere voting as the dependent variable. First, I test the main premise of protest voting: that a perceived lack of quality provided by the respondents' most preferred party increases the likelihood of an insincere vote (H1). Second, I estimate four additional models with interaction terms between the indicators of party quality, ideological incongruence and issue competence, and the two variables related to the election outcome, expected competitiveness and expected chances of winning the constituency. These four models are used to test the theorized moderating effect of strategic considerations on the relationship between perceived quality and insincere voting. ${ }^{9}$ The full replication material is available from the Harvard Dataverse (https://doi.org/10. 7910/DVN/EZDWZH). 

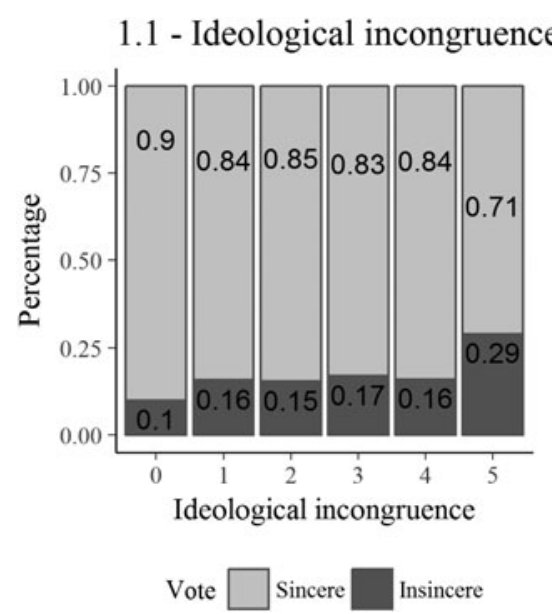

\section{2 - Party incompetence}

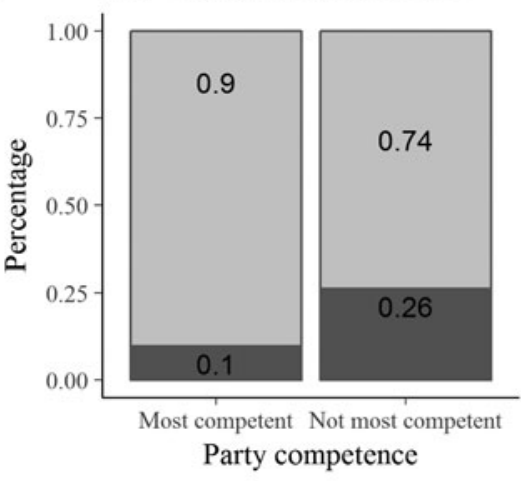

Vote $\square$ Sincere $\square$ Insincere

Figure 1. Vote Choice (Sincere/Insincere) by Perceived Ideological Incongruence to the Most Preferred Party (Fig. 1.1) and Incompetence of Most Preferred Party to Handle the Respondent's Most Important Issue (Fig. 1.2)

Note: Figure 1.1 includes 99 per cent of all valid responses $(N=1,491)$. Respondents with extreme values $(\sim 1 \%)$ on the ideological incongruence scale $(>6)$ are not shown.

\section{Results}

I begin the empirical section with some basic descriptive analyses. Figure 1 displays the bivariate relationship between the two indicators of quality and the dependent variable. We see that lower levels of quality are associated with higher levels of insincere voting. For ideological congruence (Fig. 1.1), only 10 per cent of the respondents who perceived their most preferred party to be fully congruent with their position on the left-right scale cast an insincere vote. ${ }^{10}$ An increase in incongruence is associated with more insincere voting. For party competence (Fig. 1.2), we observe a similar trend. Among those who perceive their most preferred party to be best equipped to handle the most important issue, only 10 per cent cast an insincere vote. Of those respondents who thought that either none of the parties or a party other than their most preferred were competent in that area, 26 per cent cast an insincere vote.

These observations lend some initial support to the idea that voters respond to low levels of quality by casting a protest vote. This is further investigated in the subsequent regression analyses.

Table 1 reports the results from the logistic regression analyses. Model 1 supports the initial findings from Figure 1. A decrease in ideological congruence, as well as the perception that one's most preferred party is incapable of handling the most important issue, increases the chances that voters will vote insincerely - that is, cast a protest vote. However, neither of these effects is large, and considering the standard errors, both are surrounded by high levels of uncertainty. This is further illustrated by looking at the expected probabilities at different values of the explanatory variables. For instance, the first difference between the expected probabilities to vote insincerely between the 10th and the 90th percentile of the ideological incongruence distribution is 2.1 per cent. The uncertainty ranges from $0.02 \mathrm{per}$ 
Table 1. Effect of Perceived Party Quality (Ideological Incongruence and Party Competence) on Insincere Voting

\begin{tabular}{|c|c|c|c|c|c|}
\hline & \multicolumn{5}{|c|}{ Dependent variable: Insincere vote } \\
\hline & Model 1 & Model 2A & Model 2B & Model 3A & Model 3B \\
\hline \multirow[t]{2}{*}{ Quality: Ideological incongruence } & $0.16^{\star}$ & 0.21 & $0.16^{\star}$ & 0.02 & $0.16^{\star}$ \\
\hline & $(0.07)$ & $(0.17)$ & $(0.08)$ & $(0.19)$ & $(0.07)$ \\
\hline \multirow{2}{*}{ Quality: Party incompetence } & $0.58^{\star}$ & $0.57^{*}$ & 0.86 & $0.59^{\star}$ & 0.71 \\
\hline & $(0.23)$ & $(0.23)$ & $(0.47)$ & $(0.23)$ & $(0.52)$ \\
\hline Win chance (constituency) & $\begin{array}{l}-5.08^{\star \star \star} \\
(0.72)\end{array}$ & $\begin{array}{l}-4.81^{\star \star \star} \\
(1.01)\end{array}$ & $\begin{array}{l}-4.78^{\star \star \star} \\
(0.84)\end{array}$ & $\begin{array}{l}-5.12^{\star \star \star} \\
(0.73)\end{array}$ & $\begin{array}{l}-5.08^{\star \star \star} \\
(0.72)\end{array}$ \\
\hline Expected electoral competition (constituency) & $\begin{array}{r}0.30^{\star} \\
(0.12)\end{array}$ & $\begin{array}{r}0.30^{\star} \\
(0.13)\end{array}$ & $\begin{array}{r}0.30^{\star} \\
(0.13)\end{array}$ & $\begin{array}{c}0.19 \\
(0.18)\end{array}$ & $\begin{array}{c}0.32^{\star} \\
(0.14)\end{array}$ \\
\hline $\begin{array}{l}\text { Quality: Ideological congruence } \times \text { Win chance } \\
\text { (constituency) }\end{array}$ & & $\begin{array}{c}-0.19 \\
(0.50)\end{array}$ & & & \\
\hline $\begin{array}{l}\text { Quality: Party competence } \times \text { Win chance } \\
\text { (constituency) }\end{array}$ & & & $\begin{array}{r}-1.02 \\
(1.50)\end{array}$ & & \\
\hline $\begin{array}{l}\text { Quality: Ideological congruence } \times \text { Expected } \\
\text { electoral competition (constituency) }\end{array}$ & & & & $\begin{array}{c}0.07 \\
(0.09)\end{array}$ & \\
\hline $\begin{array}{l}\text { Quality: Party competence } \times \text { Expected } \\
\text { electoral competition (constituency) }\end{array}$ & & & & & $\begin{array}{r}-0.08 \\
(0.26)\end{array}$ \\
\hline Covariates $^{a}$ & $\checkmark$ & $\checkmark$ & $\checkmark$ & $\checkmark$ & $\sqrt{-1}$ \\
\hline \multirow[t]{2}{*}{ Constant } & 0.35 & 0.29 & 0.27 & 0.53 & 0.32 \\
\hline & $(0.70)$ & $(0.73)$ & $(0.72)$ & $(0.74)$ & $(0.71)$ \\
\hline Observations & 1,139 & 1,139 & 1,139 & 1,139 & 1,139 \\
\hline Log-likelihood & -345.71 & -345.64 & -345.48 & -345.4 & -345.67 \\
\hline $\mathrm{AIC}$ & 721.42 & 723.28 & 722.95 & 722.79 & 723.34 \\
\hline
\end{tabular}

Note: Table reports log odds from logistic regression models, with standard errors in parentheses.

${ }^{a}$ Covariates adjust for the importance of the constituency and national result, party identification, preference for local and national candidates, gender, age, education and province; coefficients of covariates are not shown in this table to preserve clarity. For full results, see Table B1 in Supplementary Material Section B.

${ }^{\star} p<.05 ;{ }^{\star \star} p<.01 ;{ }^{\star \star \star} p<.001$

cent to 4.8 per cent on the 95 per cent confidence level. For party competence, we can say that the expected value to vote insincerely increases by 3.3 per cent if voters perceive their most preferred party as incompetent compared to voters who think otherwise. The uncertainty ranges from 0.5 per cent to 7.8 per cent on the 95 per cent confidence level. ${ }^{11}$ Nonetheless, even though the findings are substantially small and met with some uncertainty, this is not unexpected. The two quality indicators that were chosen here present only two of the more prominent choices of criteria based on the literature but do not offer an all-inclusive measure of party quality as perceived by the voter. Hence, these findings lend further support to the idea of protest voting as a form of signalling.

To test whether the relationship between quality and insincere voting is conditional upon the perceived chances of winning the constituency (H2) and the expected electoral competition (H3), I estimate four separate logistic regression models (Models 2A, 2B, 3A and 3B), each containing one interaction term. From Table 1, we can see that neither the perceived chances of winning the constituency seat nor the expected electoral competition in the constituency moderates the effects of quality on insincere voting on average. I further investigate these effects by plotting the average marginal effects (compare Brambor et al., 2006) in Figures 2 

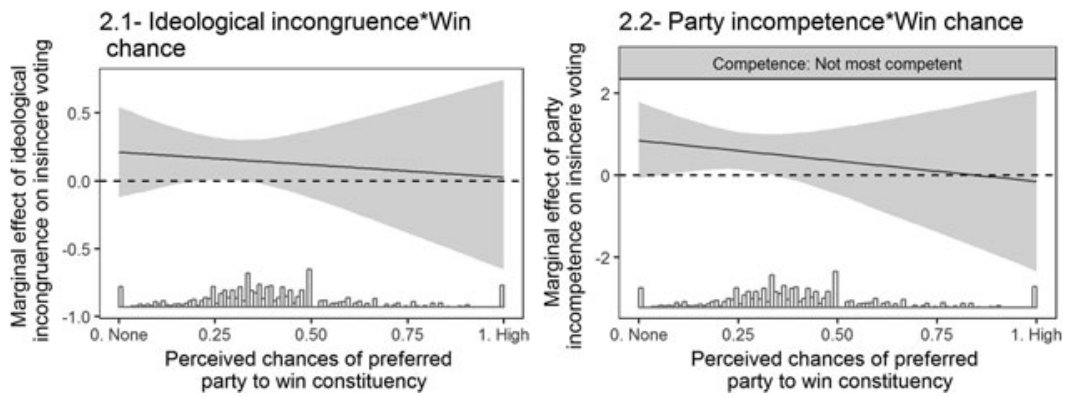

Figure 2. Average Marginal Effects of Party Quality - Ideological Congruence (Fig. 2.1) and Party Competence (Fig. 2.2) - on Insincere Voting by Perceived Chances to Win Constituency

Note: Figures are based on Model 2A (Figure 2.1) and Model 2B (Figure 2.2) in Table 1; the reference group for the average marginal effect of the party competence dummy in Figure 2.2 is "Most preferred party is competent to handle respondent's most important issue."
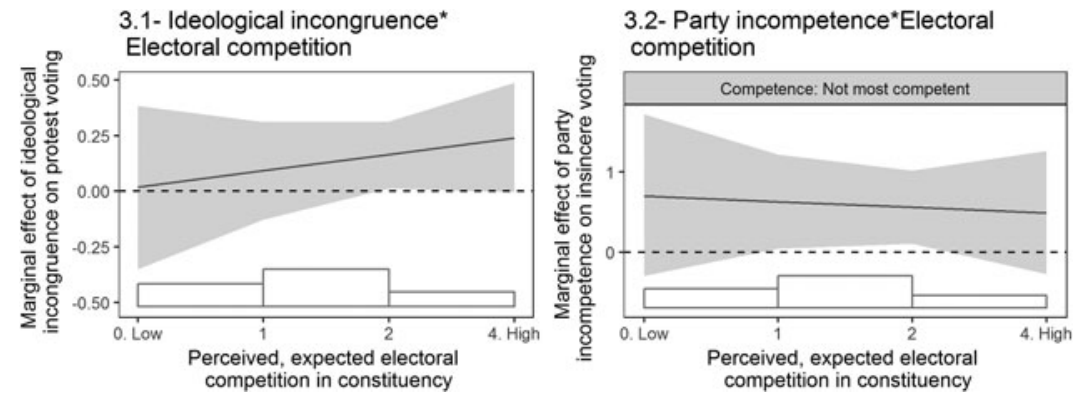

Figure 3. Average Marginal Effects of Party Quality - Ideological Congruence (Fig. 3.1) and Party Competence (Fig. 3.2) - on Insincere Voting by Expected Electoral Competition

Note: Figures are based on Model 3A (Figure 3.1) and Model 3B (Figure 3.2) in Table 1 in the article. The reference group for the average marginal effect of the party competence dummy in Figure 3.2 is "Most preferred party is competent to handle respondent's most important issue."

and 3, using critical $t$-statistics adjusted confidence intervals (compare Esarey and Sumner, 2018).

The theoretical expectation was that the more certain voters are that their preferred party will win the constituency seat, the more likely they are to react to lower quality and cast an insincere vote. Figures 2.1 and 2.2, however, show that low ideological congruence is not consistently positively associated with insincere voting across all values of perceived win chances. Moreover, the average marginal effect does not increase the more certain voters are that their most preferred party is going to win. Figure 2.2 suggests the opposite trend, although this is to be taken with caution given the uncertainty surrounding the estimates. Thus, there is no clear empirical evidence to support $\mathrm{H} 2$.

Based on $\mathrm{H} 3$, we would expect to see that voters are most likely to cast a protest vote if they anticipate that the electoral competition in their district will be low. To recap: lower competition from the respondents' point of view may mean both 1) 
that their party is likely to win, or 2) that neither their most preferred party nor any other party is likely to win. The average marginal effects from Models $3 \mathrm{~A}$ and $3 \mathrm{~B}$ are plotted in Figures 3.1 and 3.2. Again, there is little evidence to support this idea. For ideological congruence, we even see the opposite trend, with the average marginal effect increasing as respondents expect more electoral competition in their constituency. This effect, however, barely reaches conventional levels of statistical significance across all values of the conditional variable. For party competence (Fig. 3.2), we see that the average marginal effect on insincere voting is slightly higher at lower values of electoral competition. This would imply that the more voters perceive the constituency race to be settled, the more likely they are to vote insincerely. Yet at neither of the extreme values (low or high) of the conditional variable do we observe a statistically significant average marginal effect of party competence. Hence, this does not change the overall findings that neither expected win chances nor expected electoral competition conditioned the protest vote mechanism in the 2015 Canadian elections in British Columbia, Ontario and Quebec.

Overall, the analyses reveal that the two dimensions of protest voting worked as theorized. Voters were more likely to vote insincerely the lower the perceived quality was in terms of ideological congruence and competence. However, the analyses did not reveal clear evidence to support the idea that strategic considerations were moderating the relationship between the quality and insincere voting. In the subsequent robustness checks, I thus focus on testing assumptions underlying the general model of protest voting.

\section{Robustness Checks}

A key assumption made in the baseline model is that supporters of all Canadian parties react in a similar way to a decline in quality. This assumption rests on the concept of protest voting, as defined in this article, which starts from the voter's perspective. But because the previous literature primarily associates protest voting with supporters of mainstream parties (Bowler and Lanoue, 1992; McGregor, 2012), I conduct two additional tests of H1: a groupwise jackknife test (Neumayer and Plümper, 2017: 96) and an alternative model specification where a categorical variable for the most preferred party is added to the main models (see Online Supplementary Material C). The results of both tests, while adding some uncertainty, do not lead me to alter my main conclusions. A second assumption concerns the long-term perspective of voters and the subsequent decision to take into account the previous voting behaviour to restrict the set of respondents for the primary analyses. The approach allowed me to filter out potential switchers (as defined by Weber, 2011) from the analyses and added the long-term perspective built into the theory of protest voting. Yet the absence of preference information for the previous vote choice variable and inaccurate recall answers bring with it a set of other issues. Removing the restrictions to the set of analyzed respondents and defining insincere voting solely on the basis of party preferences measured before the election and the current vote choice, however, does not alter the main findings of this article (see Online Supplementary Material D). 


\section{Discussion and Summary}

In this article, I investigated the underlying dimensions of protest voting in Canada. Building on previous studies, I adopted a voter's perspective to conceive of protest voting as a deliberate insincere vote to signal discontent. The empirical analyses focused on the 2015 Canadian federal elections and revealed support for the basic mechanism of protest voting, although of a small magnitude. Voters who perceived their party as providing lower quality-measured as ideological congruence and issue competence-were more likely to vote insincerely. However, I did not find empirical patterns consistent with the idea that strategic considerations would moderate the relationship between discontent and insincere voting, as has been theorized in other studies (for example, Kselman and Niou, 2011; Myatt, 2017).

Conceptually, I highlighted the importance of adopting a voter's perspective and of considering protest voting as a concept that is built on two interacting foundations: a motive (signal discontent) and behaviour (insincere vote). I argued that such an approach allows for drawing a clear distinction between protest voting and other forms of voting, especially strategic voting. The one drawback of the concept and its implementation is that it does not allow for an easy sorting of citizens into the categories of "protest voter" and "non-protest voter." Researchers who want to know the proportion of protest voters are thus tasked with using an indirect approach-for example, similar to what Blais et al. (2005) propose for identifying the number of strategic voters. Simulation approaches may be used, for instance, to predict the percentage of respondents to whom dissatisfaction played a critical role in their decision to vote insincerely. Overall, however, the proposed concept and its implementation, which builds on previous studies (especially Weber, 2011), should inform future studies and debates about the topic of protest voting, both in Canada and elsewhere.

Empirically, the findings shed new light on a common argument made regarding protest voting-namely, that voters will only signal discontent if a win is secured (Cox, 1997; Kselman and Niou, 2011; Myatt, 2017). While Bowler and Lanoue (1992) find some support that strategic considerations mattered when Canadian protest voters chose between different options in the 1984 federal elections, the expected outcome appears to matter less for the initial decision to vote insincerely. On the one hand, this spells good news for democracy as voters hold representatives accountable for perceived shortcomings or lack of quality (Hirschman, 1970). If voters place signalling discontent over winning, parties and their candidates or representatives may utilize election results even more than before to improve their otherwise incomplete or party-biased knowledge of constituency voters' preferences (Koop, 2012). On the other hand, there may be a reason that protest voting in this form has received limited attention, primarily because it remains a limited phenomenon (McGregor, 2012; Weber, 2011). The results of this article support the latter conclusion. Even though this study revealed patterns consistent with the underlying mechanism of protest voting, the substantive effects were limited. Thus the results of elections such as the 2011 Canadian federal election, which brought about historic shifts (Fournier et al., 2013: 863) only for them to be reversed in 2015 (McGrane, 2016), are more likely the result of switching rather than temporary defection consistent with protest voting. 
Nonetheless, protest voting remains a topic worthy of more scholarly attention. For instance, this article remained limited in its scope by focusing on the 2015 elections and tackled only some of the interesting implications that theories of protest voting have developed. Others, such as the supply of viable options or the choice between a protest vote and abstention, have yet to receive extensive empirical attention (but see Bélanger, 2004). Likewise, even though there is anecdotal evidence that politicians care about protest voters, extensive systematic analyses have yet to be carried out to investigate if and how parties react to signals by a relatively small group in the electorate. Ultimately, this issue will determine if the efforts of protest voting pay off.

Supplementary material. To view supplementary material for this article, please https://oi.org/10.1017/ S0008423919000325

Acknowledgments. I presented earlier versions of this article at the University of Mannheim's Graduate School Colloquium and the 4th GESIS Political Science Roundtable and thank all participants for their useful feedback. I want to thank Ruth Dassonneville for encouraging me to write this article and Stephen Quinlan for helpful comments and his suggestion to use the terminology "underlying foundations." For further useful comments, I am grateful to Robert Huber, Nicole VT Lugosi-Schimpf, Harald Schoen, the three anonymous reviewers and the editors of the journal. I also acknowledge the support of the University of Mannheim's Graduate School of Economic and Social Sciences funded by the German Research Foundation.

\section{Notes}

1 The effect of evaluations on insincere voting is a direct effect. The term dissatisfaction is used interchangeably with any form of negative evaluation rather than as mediating variable.

2 Abstention or blank/null voting are equally considered as expressions of discontent in the literature. Kselman and Niou (2011), for instance, develop a full set of theoretical expectations under which dissatisfied voters may choose abstention as an option to cast a protest vote. Because the focus of this article, however, is not on the choice between the different options but its general applicability and conditionality, I chose to focus on the most prominent form among these options-valid votes. Blank voting occurs more frequently in emerging democracies (Cohen, 2018) and thus is a rare occurrence in Canadian elections. In the 2015 Canadian federal election, for instance, only 0.7 per cent of all ballots were declared invalid (Elections Canada, 2018).

3 This approach sets aside differences in the strength of preferences voters have for their most preferred parties. Naturally, voters dissatisfied with some aspect of their party are likely to rate their party lower than others. If the argument holds, then those with less favourable ratings of their party should also be more likely to vote insincerely (compare McGregor, 2012: 720). These differences, however, should be picked up by the indicators for aspects contributing to one's party preference, including the primary independent variables, hence justifying the dichotomous coding of respondents into sincere and insincere voters.

4 The restriction applies to 59 per cent of respondents for which there are valid answers to all variables included in the analyses.

5 Quality aspects may also refer to constituency or local level considerations.

6 An alternative to the proximity measure is a directional measure. However, as Gauvin et al. (2016) note, proximity models generally fare better in less polarized party systems, such as Canada's.

7 The category "no" includes all respondents who do not report a party identification and those who report a party identification but with a party other than their most preferred party.

8 Leader evaluations may also contribute to voters' willingness to defect, as a study on party members in Sweden and Great Britain by Polk and Kölln (2018) has shown. However, comparative research highlights the difficulties of teasing out leader effects (Mughan, 2015), which is the reason I focused on other sources of protest voting in this article. Nonetheless, the simple favourite leader comparison is added to adjust for any type of leader effects here. 
9 Analyses and figures were implemented in R (3.4.0). References to the relevant software packages are: $\mathrm{R}$ Development Core Team (2008), Wickham (2016), and Solt et al. (2018).

10 The number of respondents per bin ranges from 31 to 538. Values exceeding five on the incongruence measure are not shown because of the low number of respondents per bin (maximum $=5$ ).

11 First differences were simulated using Zelig by Choirat et al. (2017). See also Imai et al. (2008).

\section{References}

Alvarez, Michael R., Roderick D. Kiewiet and Lucas Núñez. 2018. “A Taxonomy of Protest Voting.” Annual Review of Political Science 21: 135-54.

Barry, Brian. 1974. "Review Article: Exit, Voice and Loyalty." British Journal of Political Science 4 (1): 79-107.

Beck, Paul A. 2002. "Encouraging Political Defection: The Role of Personal Discussion Networks in Partisan Desertions to the Opposition Party and Perot Votes in 1992." Political Behavior 24 (4): 309-37.

Bélanger, Éric. 2004. "Antipartyism and Third-Party Vote Choice: A Comparison of Canada, Britain, and Australia." Comparative Political Studies 37 (9): 1054-78.

Bickerton, James. 2016. "Parties and Regions: Representation and Resistance." In Canadian Parties in Transition: Recent Trends and New Paths for Research, ed. Alain-G. Gagnon and A. B. Tanguay. Toronto: University of Toronto Press.

Birch, Sarah and James Dennison. 2019. "How Protest Voters Choose." Party Politics 25 (2): 110-25.

Bittner, Amanda. 2018. "Leaders Always Mattered: The Persistence of Personality in Canadian Elections." Electoral Studies 54: 297-302.

Blais, André. 2002. "Why Is There So Little Strategic Voting in Canadian Plurality Rule Elections?” Political Studies 50 (3): 445-54.

Blais, André. 2010. "Making Electoral Democracy Work." Electoral Studies 29 (1): 169-70.

Blais, André and Jean-François Daoust. 2017. "What Do Voters Do When They Like a Local Candidate from Another Party?" Canadian Journal of Political Science 50 (4): 1103-9.

Blais, André, Eric Guntermann and Marc A. Bodet. 2017. "Linking Party Preferences and the Composition of Government: A New Standard for Evaluating the Performance of Electoral Democracy." Political Science Research and Methods 5 (2): 315-31.

Blais, André, Peter Loewen, Daniel Rubenson, Laura B. Stephenson and Elisabeth Gidengil. 2018. "Information on Party Strength and Strategic Voting: Evidence of Non-Effects from a Randomized Experiment." In The Many Faces of Strategic Voting: Tactical Behavior in Electoral Systems around the World, ed. John Aldrich, André Blais and Laura Stephenson. Ann Arbor: University of Michigan Press.

Blais, André, Richard Nadeau, Elisabeth Gidengil and Neil Nevitte. 2001. "Measuring Strategic Voting in Multiparty Plurality Elections." Electoral Studies 20 (3): 343-52.

Blais, André, Robert Young and Martin Turcotte. 2005. "Direct or Indirect? Assessing Two Approaches to the Measurement of Strategic Voting." Electoral Studies 24 (2): 163-76.

Bowler, Shaun and David J. Lanoue. 1992. "Strategic and Protest Voting for Third Parties: The Case of the Canadian NDP.” Western Political Quarterly 45 (2): 485-99.

Brambor, Thomas, William R. Clark and Matt Golder. 2006. "Understanding Interaction Models: Improving Empirical Analyses." Political Analysis 14 (1): 63-82.

Bryden, Joan. 2019. "Not Much Election Canada Can Do about Fake News Targeting Candidates." National Post, February 7. https://nationalpost.com/pmn/news-pmn/canada-news-pmn/not-much-electionscanada-can-do-about-fake-news-spread-about-candidates (February 10, 2019).

Burden, Barry C. 2005. "Minor Parties and Strategic Voting in Recent U.S. Presidential Elections." Electoral Studies 24 (4): 603-18.

Cain, Bruce E. and John Ferejohn. 1981. "Party Identification in the United States and Great Britain." Comparative Political Studies 14 (1): 31-47.

Campbell, Angus, Philip E. Converse, Warren E. Miller and Donald E. Stokes. 1960. The American Voter. New York: John Wiley.

Carter, John R. and Stephen D. Guerette. 1992. "An Experimental Study of Expressive Voting." Public Choice 73: 251-60.

Choirat, Christine, James Honaker, Kosuke Imai, Gary King and Olivia Lau. 2017. Zelig: Everyone's Statistical Software. http://ZeligProject.org (April 15, 2019). 
Cohen, Mollie J. 2018. "Protesting via the Null Ballot: An Assessment of the Decision to Cast an Invalid Vote in Latin America." Political Behavior 40 (2): 395-414.

Cox, Gary W. 1997. Making Votes Count: Strategic Coordination in the World's Electoral Systems. Cambridge: Cambridge University Press.

Cross, William, François Gélineau, Elisabeth Gidengil, Scott Pruysers, Andrea Lawlor, André Blais and Laura Stephenson. 2017. MEDW 2015 Canadian Federal Election Study. 1st ed. Harvard Dataverse. https://dataverse.harvard.edu/dataset.xhtml?persistentId=doi:10.7910/DVN/ITIJT0 (May 20, 2018).

Denemark, David and Shaun Bowler. 2002. "Minor Parties and Protest Votes in Australia and New Zealand: Locating Populist Politics." Electoral Studies 21 (1): 47-67.

Downs, Anthony. 1957. An Economic Theory of Democracy. New York: Harper \& Brothers.

Duffy, John and Margit Tavits. 2008. "Beliefs and Voting Decisions: A Test of the Pivotal Voter Model." American Journal of Political Science 52 (3): 603-18.

Elections Canada. 2018. "Forty-Second General Election 2015: Official Voting Results.” August 27. http:// www.elections.ca/res/rep/off/ovr2015app/41/table11E.html (January 21, 2019).

Esarey, Justin, and Jane L. Sumner. 2018. "Marginal Effects in Interaction Models: Determining and Controlling the False Positive Rate.” Comparative Political Studies 51 (9): 1144-76.

Fiorina, Morris P. 1981. Retrospective Voting in American National Elections. New Haven: Yale University Press.

Fisher, Stephen D. 2004. "Definition and Measurement of Tactical Voting: The Role of Rational Choice." British Journal of Political Science 34 (1): 152-66.

Fournier, Patrick, Fred Cutler, Stuart N. Soroka, Dietlind Stolle and Éric Bélanger. 2013. "Riding the Orange Wave: Leadership, Values, Issues, and the 2011 Canadian Election." Canadian Journal of Political Science 46 (4): 863-97.

Fraga, Bernard L. and Eitan D. Hersh. 2018. "Are Americans Stuck in Uncompetitive Enclaves? An Appraisal of U.S. Electoral Competition." Quarterly Journal of Political Science 13 (3): 291-311.

Franklin, Mark N., Richard Niemi and Guy D. Whitten. 1994. “The Two Faces of Tactical Voting." British Journal of Political Science 24 (4): 549-57.

Gauvin, Jean-Philippe, Chris Chhim and Mike Medeiros. 2016. "Did They Mind the Gap? Voter/Party Ideological Proximity between the BQ, the NDP and Quebec Voters, 2006-2011." Canadian Journal of Political Science 49 (2): 289-310.

Gehlbach, Scott. 2006. “A Formal Model of Exit and Voice.” Rationality and Society 18 (4): 395-418.

Gidengil, Elisabeth, Neil Nevitte, André Blais, Joanna Everitt and Patrick Fournier. 2012. Dominance and Decline: Making Sense of Recent Canadian Elections. Toronto: University of Toronto Press.

Graves, Frank and Michael Valpy. 2018. "Canada Is a Tinderbox for Populism. The 2019 Election Could Spark It.” Maclean's, December 3. https://www.macleans.ca/politics/canada-is-a-tinderbox-forpopulism-the-2019-election-could-spark-it/ (February 10, 2019).

Healy, Andrew and Neil Malhotra. 2013. "Retrospective Voting Reconsidered." Annual Review of Political Science 16 (1): 285-306.

Heath, Anthony F., Roger Jowell and John Curtice. 1985. How Britain Votes. Oxford: Pergamon Press.

Herrmann, Michael, Simon Munzert and Peter Selb. 2016. "Determining the Effect of Strategic Voting on Election Results.” Journal of the Royal Statistical Society: Series A (Statistics in Society) 179 (2): 583-605.

Hirschman, Albert O. 1970. Exit, Voice, and Loyalty: Responses to Decline in Firms, Organizations, and States. Cambridge, MA: Harvard University Press.

Imai, Kosuke, Gary King and Olivia Lau. 2008. "Toward a Common Framework for Statistical Analysis and Development." Journal of Computational and Graphical Statistics 17 (4): 892-913.

Ivarsflaten, Elisabeth. 2008. "What Unites Right-Wing Populists in Western Europe? Re-examining Grievance Mobilization Models in Seven Successful Cases." Comparative Political Studies 41 (1): 3-23.

Kang, Won-Taek. 2004. "Protest Voting and Abstention under Plurality Rule Elections: An Alternative Public Choice Approach.” Journal of Theoretical Politics 16 (1): 79-102.

Key, Vladimir O. 1966. The Responsible Electorate: Rationality in Presidential Voting 1936-1960. Cambridge, MA: Harvard University Press.

Koop, Royce. 2012. "Party Constituency Associations and the Service, Policy and Symbolic Responsiveness of Canadian Members of Parliament." Canadian Journal of Political Science 45 (2): 359-78.

Kselman, Daniel and Emerson Niou. 2011. "Protest Voting in Plurality Elections: A Theory of Voter Signaling.” Public Choice 148 (3-4): 395-418. 
McGrane, David. 2016. "From Third to First and Back to Third: The 2015 NDP Campaign." In The Canadian Federal Election of 2015, ed. Jon H. Pammett and Christopher Dornan. Toronto: Dundurn.

McGregor, Robert M. 2012. "Voter Sincerity and the Time-of-Voting-Decision." Electoral Studies 31 (4): $715-25$.

McMurray, Joseph. 2017. "Voting as Communicating: Mandates, Multiple Candidates, and the Signaling Voter's Curse." Games and Economic Behavior 102: 199-223.

Meirowitz, Adam and Kenneth W. Shotts. 2009. "Pivots versus signals in elections." Journal of Economic Theory 144 (2): 744-71.

Meirowitz, Adam and Joshua A. Tucker. 2007. "Run Boris Run: Strategic Voting in Sequential Elections." Journal of Politics 69 (1): 88-99.

Merolla, Jennifer L. and Laura B. Stephenson. 2007. "Strategic Voting in Canada: A Cross Time Analysis." Electoral Studies 26 (2): 235-46.

Mughan, Anthony. 2015. "Parties, Conditionality and Leader Effects in Parliamentary Elections." Party Politics 21 (1): 28-39.

Myatt, David P. 2017. “A Theory of Protest Voting.” Economic Journal 127 (603): 1527-67.

Neumayer, Eric and Thomas Plümper. 2017. Robustness Tests for Quantitative Research. Methodological Tools in the Social Sciences. Cambridge: Cambridge University Press.

Piketty, Thomas. 2000. "Voting as Communicating." Review of Economic Studies 67 (1): 169-91.

Polk, Jonathan and Ann-Kristin Kölln. 2018. "Electoral Infidelity: Why Party Members Cast Defecting Votes." European Journal of Political Research 57 (2): 539-60.

Razin, Ronny. 2003. "Signaling and Election Motivations in a Voting Model with Common Values and Responsive Candidates.” Econometrica 71 (4): 1083-1119.

R Development Core Team. 2008. R: A Language and Environment for Statistical Computing. Vienna, Austria: R Foundation for Statistical Computing.

Schumacher, Gijs and Matthijs Rooduijn. 2013. "Sympathy for the 'Devil'? Voting for Populists in the 2006 and 2010 Dutch General Elections." Electoral Studies 32 (1): 124-33.

Solt, Frederick, Yue Hu and Brenton Kenkel. 2018. Package 'interplot.' https://cran.rproject.org/web/packages/interplot/vignettes/interplot-vignette.html (April 15, 2019).

Somer-Topcu, Zeynep. 2009. "Timely Decisions: The Effects of Past National Elections on Party Policy Change." Journal of Politics 71 (1): 238-48.

Stiers, Dieter. 2018. "Beyond the Distinction Incumbent-Opposition: Retrospective Voting on the Level of Political Parties." Party Politics (Online First): 1-13.

Van der Brug, Wouter, Meindert Fennema and Jean Tillie. 2000. "Anti-Immigrant Parties in Europe: Ideological or Protest Vote?” European Journal of Political Research 37 (1): 77-102.

Weber, Till. 2011. "Exit, Voice, and Cyclicality: A Micrologic of Midterm Effects in European Parliament Elections." American Journal of Political Science 55 (4): 907-22.

Wickham, Hadley. 2016. ggplot2: Elegant Graphics for Data Analysis. 2nd ed. New York: Springer.

Cite this article: Schimpf CH (2019). Anticipated Election Result and Protest Voting: Why and When Canadian Voters Signal Discontent. Canadian Journal of Political Science 52, 847-863. https://doi.org/ $10.1017 /$ S0008423919000325 